\title{
Growth Performance, Feed Efficiency and Survival Rate of Milk Fish (Chanos-chanos) Juvenile as Affected by Replacement of Fish Meal by Telescopium Mussel Meal in the Diet
}

\author{
Agus Kurnia ${ }^{1}$, Wellem H. Muskita ${ }^{2}$, Oce Astuti ${ }^{3}$, Muhaimin Hamzah ${ }^{4}$, Adnan Hakim², Marselani ${ }^{6}$ \\ 1,2,3,4, ${ }^{6}$ Laboratory of Fish Nutrition, Department of Aquaculture, Faculty of Fisheries and Marine Science, Halu Oleo University
}

${ }^{5}$ Department of Management, Faculty of Economic and Business, Halu Oleo University

\begin{abstract}
The objectives of the study were to determine the effect of replacement of fish meal (FM) by telescopium mussel meal (TMM) on growth performance, feed efficiency and survival rate of juvenile milk fish (Chanos-chanos, initial body weight $0.25 \pm 0.04$ g). Five replacing levels $(0,25 \%, 50 \%, 75 \%$ and $100 \%$ of fishmeal protein were replaced by TMM protein) were prepared. One diet from commercial diet was a control diet. The experiment was designed by using Completely Randomized Design (CRD) with 6 treatments and 3 replications. The study showed that substitution FM with TMM was a significantly $(P<0,05)$ on absolutely growth, specific growth rate and survival rate but it was not significantly $(P>0,05)$ on feed convertion ratio and feed efficiency. The absolutely growth was highest in the fish fed diet $B(0,87 \pm 0,25 \mathrm{~g})$. While, survival rate was highest in the fish fed $E(100 \%$ TMM) that was $60,6 \pm 3,44 \%$. This study concluded that replacement $25 \%$ of FM with TMM in the diet could improve the growth and survival rate of milkfish juvenile
\end{abstract}

Keywords: Fish meal, Telescopium mussel meal, replacement, growth performance, survival rate, Milk fish

\section{Introduction}

Milk fish,so-called bandeng is one of the most popular seafood in Indonesia. It is an omnivorous species and has been widely cultured in pond and net cage along the coast of northern cost of java and southern coast of Sulawesi Island, Indonesia. As human consumption, milkfish has been demand especially in central and east Java and south Sulawesi. Nowadays, milkfish culture is aimed not only for human consumption but also for bait fish for tuna and skipjack fishing.

Commonly in fish culture, feed require $40-60 \%$ of total production cost; thus, recent effort to determine specific nutrient requirements and evaluate inexpensive practical diets have been devoted to reduce diet costs and possibly increase profits (Jacinto et al. 2003; Muzinic et al. 2004; Jacinto et al. 2005; Thompson et al. 2005).

One of the most expensive of ingredients is fish meal. Fish meal is the most important component in practical diets for aquaculture, however since decreasing of fishing production in last two decades, the price of fish meal became more expensive than before. Fish meal (FM) is considered the most desirable animal protein ingredient in aquaculture diets because of its high protein content, balanced amino acid profiles, high digestibility and palatability, and as a source of essential $n-3$ polyenoic fatty acids.

However, FM is one of the most expensive macroingredients (used in high percentages) in an aquaculture diet. Likewise, with the static or declining fish populations that are used to produce FM, the view held by some is that the use of FM in aquaculture diets is wasteful and unethical. The high cost of FM and concerns regarding its future availability have made it imperative for the aquaculture industry to reduce or eliminate FM from fish and crustacean diets. One approach aquaculture nutritionists have embraced is to partially or totally substitute FM with less expensive animal and/or plant protein sources. Therefore, demand alternative ingredients as protein source is very crucial.

Cost effectiveness of the feed could be improved by replacing fish meal with more economical protein sources, such as rendered animal protein ingredients, e.g., (PBM), meat and bone meal (MBM) and feather meal (FM). These ingredients have been used successfully in feeds for various fish species, such as chinook salmon (Fowler, 1991), silver seabream (El-Sayed, 1994), rainbow trout (Steffens, 1994; Bureau et al., 2000), red drum (Moon and Gatlin, 1994; Kureshy et al., 2000), gilthead seabream (Robaina et al., 1997; Nengas et al., 1999), Indian major carp (Hasan et al., 1997), Australian snapper (Quartararo et al., 1998), Australian silver perch (Allan et al., 2000; Stone et al., 2000), Nile tilapia (El-Sayed, 1998), sunshine bass (Webster et al., 2000) and grouper (Milliamena, 2002).

The other protein alternative source that potentially to replace fish meal is telescopium meal. Mangrove shells (Telescopium telescopium), are one of gastrophodes which are found in large quantities in mangrove areas and fish ponds. These shells has economical value and are consumed as dishes, and also has the avantage as asthma medicine. However, the shells is also a feeding competitor for milkfish and shrimp. The protein and lipid content of Telescopium meal were $67.6 \%$ and $6.35 \%$ dry weight, respectively (Kurnia, 2012). Therefore it is potentially to replace fish meal in the diet of milk fish.

The present study was conducted to assess the effect of using telescopium mussel meal ( TM) as an ingredients 


\section{International Journal of Science and Research (IJSR) \\ ISSN (Online): 2319-7064 \\ Index Copernicus Value (2015): 78.96 | Impact Factor (2015): 6.391}

replacement of fish meal in the practical diet on growth, feed conversion ratio and survival rate of milk fish.

\section{Material and Methods}

\subsection{Feed formulation and preparation}

Mangrove snail (Telescopium telescopium) was collected in the shrimp pond from Kendari and Moramo district. While, the other feed ingredients such as fish meal, corn meal, sago meal, wheat meal, fish oil and top mix were obtained from the local feed ingredient shops and traditional market. The feed ingredients and proximate composition of feed are presented in Table 1. Five dry feeds were formulated to contain 38\% digestible protein and $8 \%$ digestible lipid. One diet of commercial diet was a control diet and this feed served as acomparison to the formulated feeds. The Diet A as a representative with $100 \%$ of fish meal contained 450 $\mathrm{kg} . \mathrm{g}^{-1}$ of jack mackerel meal. In the other four diets, TM was included at $112.5,225,337.5$ and $450 \mathrm{~g} . \mathrm{kg}^{-1}$ (diet B, diet C, diet $\mathrm{D}$, and diet $\mathrm{E}$, respectively) which correspond to 25,50 , 75 and 100\% TM replacement. Diet samples were subjected to proximate composition analysis, the results of which are represented in also in Table 1.

Table 1: Feed ingredients and proximate analysis of feed test of milk fish

\begin{tabular}{|c|c|c|c|c|c|c|}
\hline Ingredients & \multicolumn{7}{|c|}{ Feed experiment $\left(\mathrm{g} . \mathrm{kg}^{-1}\right)$} & \\
\hline & $\mathrm{A}$ & $\mathrm{B}$ & $\mathrm{C}$ & $\mathrm{D}$ & $\mathrm{E}$ & $\mathrm{F}$ \\
\hline Jackerel meal & 450 & 337,5 & 225 & 112,5 & 0 & - \\
\hline Telescopium meal & 0 & 112,5 & 225 & 337,5 & 450 & - \\
\hline Soy bean meal by product & 100 & 110 & 110 & 120 & 140 & - \\
\hline Braine meal & 80 & 80 & 80 & 70 & 80 & - \\
\hline Sagou meal & 70 & 70 & 70 & 70 & 80 & - \\
\hline Corn meal & 90 & 90 & 80 & 80 & 70 & - \\
\hline Wheat gluten meal & 150 & 140 & 150 & 150 & 120 & - \\
\hline Coconut oil & 20 & 20 & 20 & 20 & 20 & - \\
\hline Fish oil & 20 & 20 & 20 & 20 & 20 & - \\
\hline Top Mix* & 20 & 20 & 20 & 20 & 20 & - \\
\hline Total & 1000 & 1000 & 1000 & 1000 & 1000 & - \\
\hline Result of Proximate analysis & & \\
\hline fiber (\%) & 4,86 & 3.44 & 5.20 & 4.55 & 6.73 & 5.81 \\
\hline Crude protein (\%) & 37,76 & 36.64 & 35.52 & 36.39 & 35.55 & 19.50 \\
\hline Crude lipid(\%) & 12,68 & 16.52 & 16.83 & 17.12 & 16.20 & 6.74 \\
\hline Moisture (\%) & 14,67 & 12.03 & 12.10 & 11.78 & 12.25 & 12.20 \\
\hline Ash (\%) & 8,44 & 8.09 & 8.20 & 8.57 & 7.39 & 6.44 \\
\hline BETN & 21.59 & 23.28 & 22.15 & 21.59 & 21.88 & 49.31 \\
\hline Vitamin A, D3 & E, K, B1, B2 & B6 & B 12 & C, & Ca-D
\end{tabular}

Note : *) Vitamin A, D3, E, K, B1, B2, B6, B12, C, Ca-Dpantothenate, Niacin, Cholin Chloride, Methionine, Lysine, Manganese, Iron, Lodine, Zine, Cobalt, Copper, Santoquin (Antioxidant), Zine bacitraein.

\section{Fish and experimental conditions}

An a 6-weeks feeding trial was conducted at the Hatchery belong to Department of Fishery and Marine Affairs, Ministry of Fishery and Marine Affairs, Kendari, South-east Sulawesi, Indonesia. Juvenile milk fish were obtained from Fish Hatchery in Situbondo east Java. Indonesia. One week prior to the start of the feeding trial, the milk fish were acclimated to experimental condition and all fish fed with commercial diet.
A total of 720 fish (Initial weight: $0.25 \pm 0.06 \mathrm{~g}$; mean $\pm \mathrm{SD}$ ), were randomly distributed in 18 , 60-L Styrofoam boxes of $40 \mathrm{fish} / \mathrm{box}$. This protocol was preferred to offering pellets from the different diets, which might have resulted in differential feed intake, and thus incomplete acclimation for one or several diets. In this period of acclimation, all dead or apparently stressed fish were replaced with individuals of similar sizes.

During the trial, the fish were hand fed three times at 08:00, 12.00 and 16:00 h daily. At each feeding, some pellets were dropped in each tank until no feeding activity of fish was observed. Dead fish were recorded and weighed for calculating feed conversion ratio (FCR). Sampling for fish weight was performed every two weeks, it is four times of fish weighting Water temperature was measured daily and salinity weekly. Water temperature ranged from 28 to $31^{\circ} \mathrm{C}$, and salinity was maintenance at $20 \mathrm{ppt}$ during the feeding trial.

\section{Diet analysis}

Experimental diets were analysed to determine moisture, protein, lipid, fibre, and ash. Moisture was determined by the placement of a 2-g sample into a convection oven (135_C) for $2 \mathrm{~h}$ until constant weight (AOAC procedure 930.15, 1995); protein was determined by kjeldhal method (AOAC procedure 990.03, 1995); lipid was determined by soxhlet method (AOAC procedure 954.02, 1995); fibre was determined by using the fritted-glass crucible method (AOAC procedure 962.09, 1995); and ash was determined by placing a 2-g sample in a muffle furnace $\left(600 \_\mathrm{C}\right)$ for $2 \mathrm{~h}$ (AOAC 942.05, 1995). Proximate composition of each of the six experimental diets are presented in Tables 1.

\section{Data calculations and Statistical analysis}

The criteria used to determinate growth and feed conversion ratio were:

Absolutely Weight = Mean final biomass - mean initial biomass

$\mathrm{SGR}=100(\operatorname{Ln}($ mean final body weight $)-\operatorname{Ln}($ mean initial body weight) $)$ /time (days)

$\mathrm{FCR}=$ dry feed intake $(\mathrm{g}) /($ final biomass $(\mathrm{g})$ - initial

biomass $(\mathrm{g})+$ biomass of the dead fish $(\mathrm{g}))$

Survival $(\%)=100(\mathrm{f}$ inal $\mathrm{f}$ ish number/initial $\mathrm{f}$ ish number $)$

Overall growth data were analysed by ANOVA using the SPSS version 16. General Linear Models (SAS software version 8.2; SAS 1999). Means of the six treatments (diets) were compared using least-significant difference (LSD). Data were analysed by a one-factor ANOVA, with or without FM, as the factors, and Weight gain, feed conversion ratio (FCR), percent survival, and total yield $(\mathrm{kg}$. $\left.\mathrm{ha}^{-1}\right)$ as the three dependent variables. All percentage and ratio data were transformed to arc sin values prior to statistical analysis (Zar 1984). All statistical computations were performed at the $\mathrm{P}<0.05$ probability level.

\section{Results}

\section{Growth and feed utilization efficiency}

At the end of experiment, rearing the fish for 42 days, The absolutely growth of fish are shown in Figure 1. Fish fed 
diets $\mathrm{A}, \mathrm{B}$ and $\mathrm{C}$ showed significant higher in weight gain $(\mathrm{P}<0.05)$ than that of fish fed diets $\mathrm{D}, \mathrm{E}$ and $\mathrm{F}$.

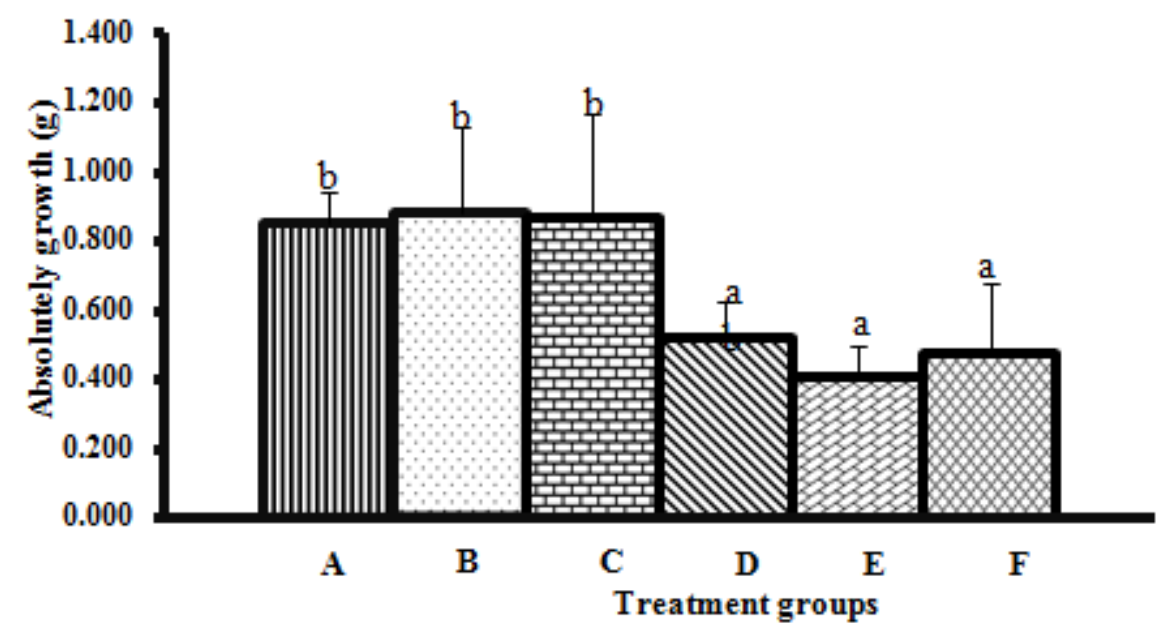

Figure 1: Absolutely growth of milk fish. Diet A (100\% FM); Diet B (75\% FM + 25\% TMM); Diet C (50\% FM + 50\% TMM); Diet (25\% FM+ 75\% TMM); pakan E (100\% TMM); Diet F (Control diet)

The results showed that the highest of weight gain was obtained in the fish diet $\mathrm{B}(0,87 \pm 0,25 \mathrm{~g})$ and followed by the fish fed diet $\mathrm{C}(0,86 \pm 0,29 \mathrm{~g})$, diet $\mathrm{A}(0,85 \pm 0,09 \mathrm{~g})$, diet $\mathrm{D}$ $(0,51 \pm 0,10 \mathrm{~g})$, diet $\mathrm{F}(0,47 \pm 0,20 \mathrm{~g})$ and $\operatorname{diet} \overline{\mathrm{E}}(0,40 \pm 0,09 \mathrm{~g})$, respectively. According to the analysis of one-way ANOVA, replacement of FM with TMM in the diet significantly affected to the absolutely growth of milk fish juvenile $(\mathrm{p}<$ 0.05).
While, the fish fed diet A had highest in the SGR of the fish. The fish fed diet $\mathrm{B}$ and diet $\mathrm{C}$ were higher than the fish fed diet D, diet E and F. Statistical analysis showed that the test diet were significantly different in SGR (p<0.01).(Fig. 2).

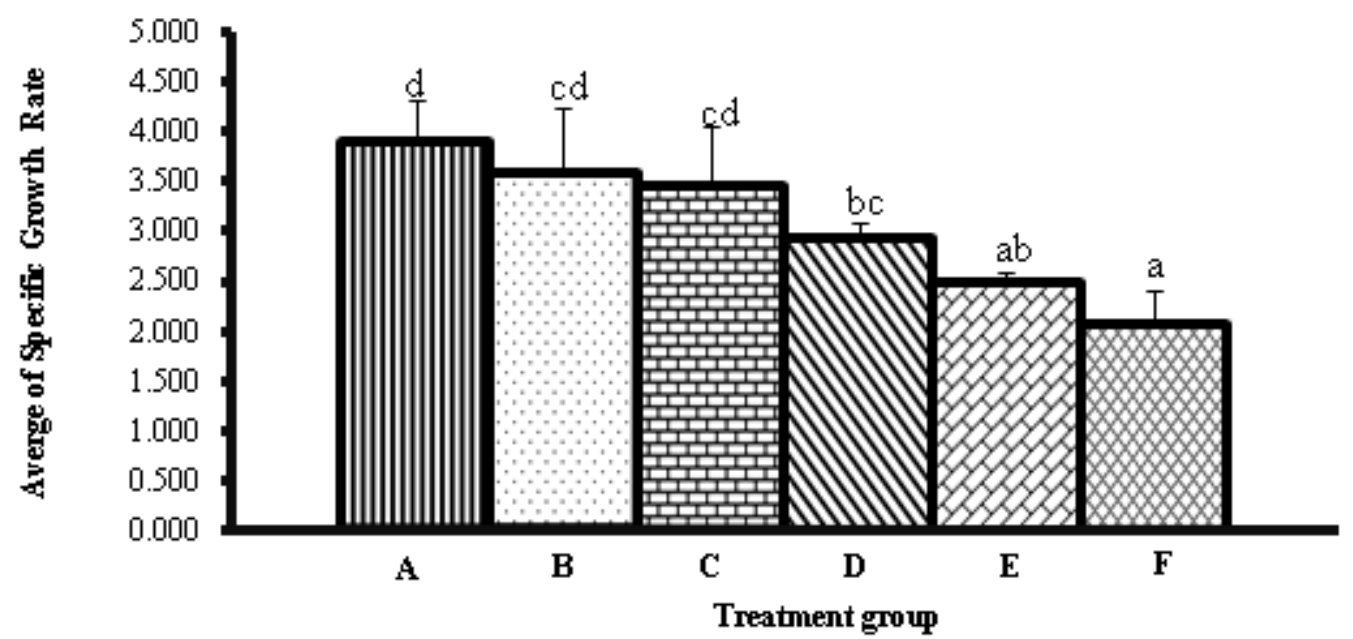

Figure 2: Specific growth rate of milkfish

The highest of FCE was observed in the fish fed diet $\mathrm{C}$ $(1,15 \pm 0,43)$ and followed by the fish fed diet $\mathrm{B}(1,13 \pm 0,33)$, $\operatorname{diet} \bar{A}(1,10+0,13)$, diet $\mathrm{D}(0,73+0,12)$ and $\overline{\operatorname{diet}} \mathrm{F}$ $(0,66 \pm 0,28)$. While, the lowest of FCE was found in the fish fed diet $\mathrm{E}(0,57 \pm 0,08)$. According to the statistically analysis showed that all of the treatment has no significantly different for FCE ( $\mathrm{P}>0.05$ ) (Fig.3). 
International Journal of Science and Research (IJSR)

ISSN (Online): 2319-7064

Index Copernicus Value (2015): 78.96 | Impact Factor (2015): 6.391

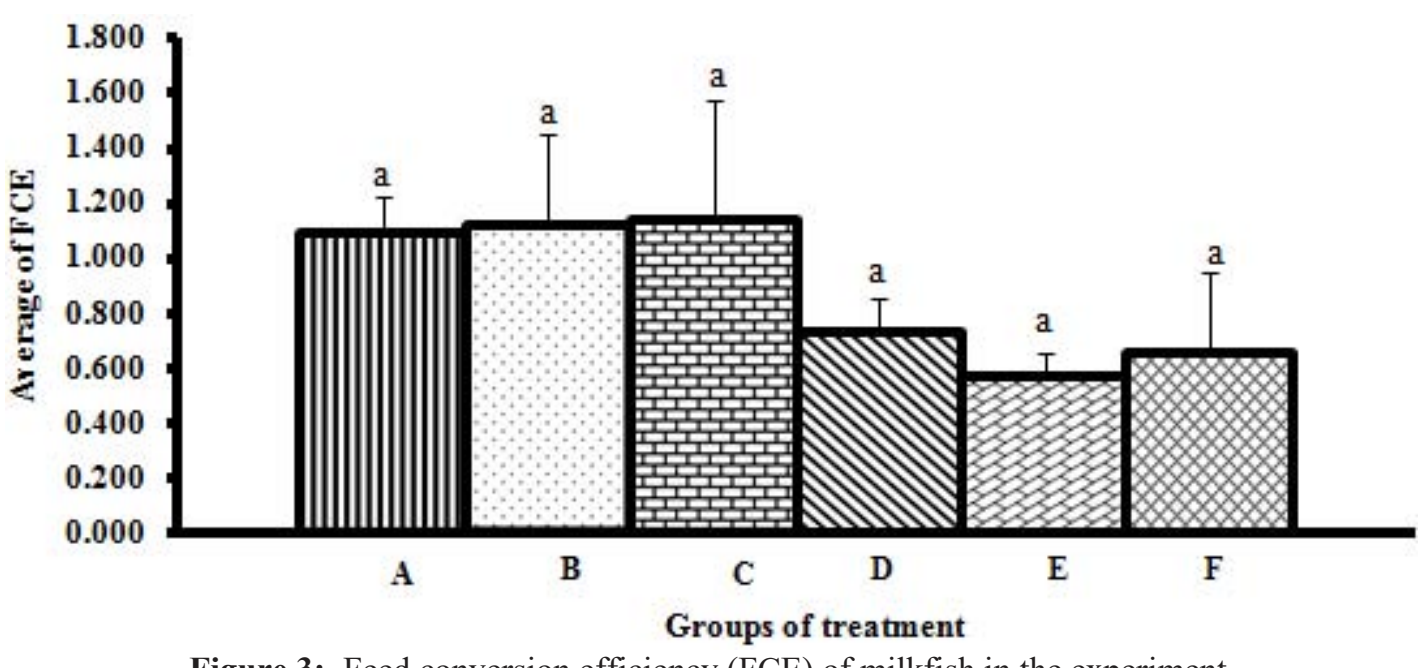

Figure 3: Feed conversion efficiency (FCE) of milkfish in the experiment

There was a significantly different in the survival rate (SR) of fish $(p<0.05)$. The fish fed formulated $\operatorname{diet}(\operatorname{diet} A$, diet $\mathrm{B}$, diet $\mathrm{C}$, diet $\mathrm{D}$ and $\operatorname{diet} \mathrm{E}$ ) has higher in SR compared to the commercial diet (figure 4). The highest of SR was observed in the fish fed diet $\mathrm{E}$ and followed by the fish fed $\operatorname{diet} \mathrm{D}$, diet $\mathrm{A}$, diet $\mathrm{B}$, diet $\mathrm{C}$ and the lowest is the fish fed $\operatorname{diet} \mathrm{F}$.

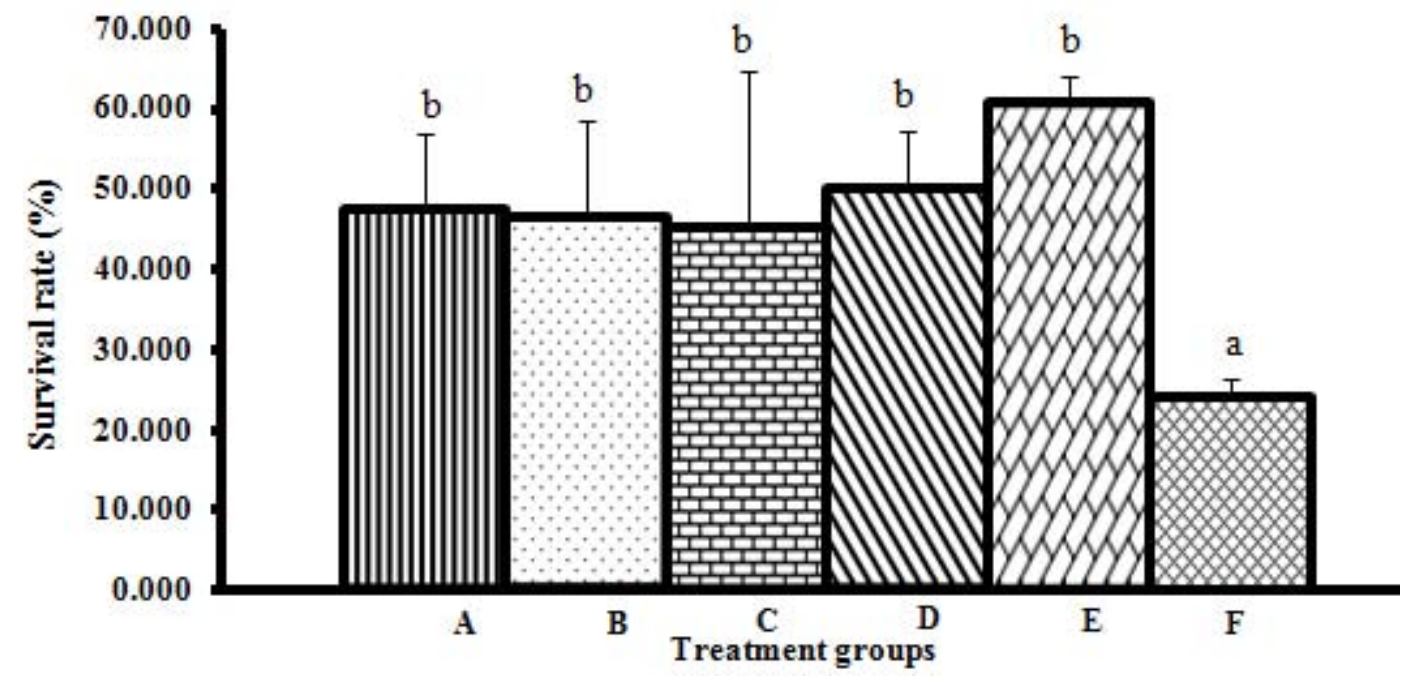

Figure 4: Results of Survival rate of the fish

\section{Discussion}

During the experiment, water quality in all treatments maintained within the optimum range required by milkfish (Ballarind Hatton, 1979). Our results demonstrated significantly difference among fish fed the diet A (100\% FM), diet B (75\% FM : 25\% TMM)and C (50\% FM : 50\% TMM) and those fed either diet D (25\% FM : 75\% TMM), diet E (100 TMM) or control diet in terms of absolutely growth. The absolutely growth decreased when the dietary TMM content exceeded 50\%. Milk fish fed the commercial diet exhibited lower SGR and absolutely growth than the fish fed formulated diet. The fish fed diet A showed very similar growth to fish fed containing $25 \%$ TMM or $50 \%$ TMM, and exhibited similar in SGR, FCE and SR, suggesting replaced dietary FM to $25 \%$ or $50 \%$ of dietary TMM. This finding is in agreement with Cruz-Suarez et al. ( 1993) who found that shrimp (P. vannamei) fed a diet containing commercial fish meal had reduced growth compared to that of shrimp fed diets containing shrimp byproduct meals. The inferior growth performance obtained with commercial diet could have been due to differences in protein quality (lower protein content in the diet) related to species or source (origin; age/size) or to differences in processing techniques. For example, the degree of heat treatment can affect bioavailability of essential amino acids, particularly lysine and methionine (Knipfel, 1981 ; Hurrell and Finot, 1985; Tanksley and Knabe, 1985), the digestibility of feed ingredients (McDonald et al., 1988) or the level of antinutritional factor, thiaminase (NRC, 1983)

Incorporation of the TMM in feed formulation at $11.25 \%$ to $22.5 \%$ (to replace $25 \%$ to $50 \%$ of the fish meal) did not any results in significantly negative effects on weight gain, SGR, FCR and SR, suggesting the TMM is an adequate protein ingredient for milkfish juvenile. The TMM used in the present study had high protein and lipid contents and balanced amino. Results of proximate composition showed that the TMM was similar to poultry by-product meal (PBM). Because of limiting information the utilization of TMM in formulated diet, the effect of incorporated of 


\section{International Journal of Science and Research (IJSR) \\ ISSN (Online): 2319-7064 \\ Index Copernicus Value (2015): 78.96 | Impact Factor (2015): 6.391}

TMM might be similarly effect with incorporated of PBM in the diet. In previous studies, PBM have been demonstrated successful in use at $20 \%$ in feeds for chinook salmon (Fowler, 1991), 25\% for silver seabream (El-Sayed, 1994), $21 \%$ for Australian snapper (Quartararo et al., 1998), 71\% for gilthead seabream (Nengas et al., 1999), and 14\% for red drum (Kureshy et al., 2000), although declined growth performance was observed in Australian silver perch (Allan et al., 2000) and sunshine bass (Webster et al., 2000) fed feeds containing high PBM level. The results of the present study confirm the conclusions and indicate the TMM could be directly used at $25 \%$ in feeds for obtain the optimum growth of milk fish.

Nutritional benefits of using combinations of various animal , such as PBM, FM and bone meal (BM ) (Fowler, 1991), PBM and FM (Steffens, 1994), PBM and SM (Quartararo et al., 1998), MBM and SBM (Webster et al., 2000), MBM and BM (Milliamena, 2002) have been demonstrated for many fish species. In the present study, a combination FM and TMM in formulated diet has might more relatively higher in amino acid content than only incorporated of FM or TMM in the diet. Fish fed the diet B had higher in SGR and final body weight (FBW) than fish fed the control feed, but did not show any difference in SGR and FBW compared with fish fed the feeds in which either TMM replaced $100 \%$ to $50 \%$ of the fish meal or TMM replaced $25 \%$ of the fish meal. The present study concluded that inclusion $25 \%$ of TMM to replace FM could be recommended in the diet of milk fish and also the TMM could be potentially usage as an alternative protein source to replace the fish meal in the diet of milkfish.

\section{Acknowledgements}

We thank Mr. Muh. Nasbir, and other staff, Shrimp Hatchery Centre, Department of Fishery and Marine Affair, Southeast Sulawesi Province, Indonesia for providing facilities and helping in the feeding trial. We also thank $\mathrm{Hj}$. Indriyani Nur, Ph.D, Head of Text Laboratory for providing facilities for proximate analysis in Laboratory of Faculty of Fisheries and Marine Science, Halu Oleo University, Kendari Southeast Sulawesi Indonesia.

\section{References}

[1] Allan, G.L., Rowland, S.J., Mifsud, C., Glendenning, D., Stone, D.A.J., Ford, A., 2000. Replacement of fish meal in diets for Australian silver perch, Bidyanus bidyanus $\mathrm{V}$. Least-cost formulation of practical diets. Aquaculture 186, 327-340.

[2] Bureau, D.P., Harris, A.M., Bevan, D.J., Simmons, L.A., Azevedo, P.A., Cho, C.Y., 2000. Feather meals and meat and bone meals from different origins as protein sources in rainbow trout (Oncorhynchus mykiss) diets. Aquaculture 181, 281-291.

[3] Cruz-Suarez, L.E., Ricque-Marie, D., Martinez-Vega, J.A. and Wesche-Ebeling, P., 1993. Evaluation of two shrimp by-product meals as protein sources in diets for Penaeus uannamei. Aquaculture, 115: 53-62.

[4] El-Sayed, A.F.M., 1998. Total replacement of fish meal with animal protein sources in Nile tilapia. Aquac. Res. $29,275-280$.
[5] Fowler, 1991. Poultry by product meal as a dietary protein source in fall Chinook salmon diet. Aquaculture, 99. $309-321$

[6] Hasan, M.R., Haq, M.S., Das, P.M., Mowlah, G., 1997. Evaluation of poultry-feather meal as a dietary protein source for Indian major carp. Labeo rohita fry. Aquaculture 151, 47-54.

[7] Hurrell, R.F. and Finot, P.A., 1985. Effects of food processing on protein digestibility and amino acid availability. In: J. W. Finley and D.T. Hopkins (Editors), Digestibility and Amino Acid Availability in Cereals and Oilseeds. American Assoc. of Cereal Chemists, Inc., St. Paul, MN, pp. 233-246.

[8] Jacinto, E.C., Colmenares, H.V., Suarez, L.E.C., Cerecedo, R.C.,Soria, H.N. \& Llamas, A.H. 2005. Effect of different dietary protein and lipid levels on growth and survival of juvenile Australian redclaw crayfish, Cherax quadricarinatus (von Martens). Aquacult. Nutr., 11, 283-291.

[9] Knipfel, J.E., 1981. Nitrogen and energy availabilities in foods and feeds subjected to heating. In: C. Eriksson (Editor), Maillard Reactions in Food. Prog. Fd. Nutr. Sci., 5 (1-6): 177-192.

[10] Kureshy, N., Davis, D.A., Aronld, C.D., 2000. Partial replacement of fish meal with meat-and-bone meal, flash-dried poultry by product meal, enzyme digested poultry by-product meal in practical diets for juvenile red drum. N. Am. J. Aquac. 62, 266-272.

[11] McDonald, P., Edwards, R.A. and Greenhalgh, J.F.D., 1988. Animal Nutrition (Evaluation of Food), 4th edn. John Wiley and Sons, Inc., New York, pp. 200-215.

[12] Milliamena, O.M., 2002. Replacement of fish meal by animal byproduct meals in a practical diet for grow-out culture of grouper, Epinephelus coioides. Aquaculture 204, 75- 84.

[13] Moon, H.Y.L., Gatlin III, D.M., 1994. Effects of dietary animal proteins on growth and body composition of the red drum (Sciaenops ocellatus). Aquaculture 120, 327 340.

[14] Muzinic, L.A., Thompson, K.R., Morris, A., Webster, C.D., Rouse, D.B. \& Manomaitis, L. (2004) Partial and total replacement of fish meal with soybean meal and brewer's grains with yeast in practical diets for Australian red claw crayfish, Cherax quadricarinatus. Aquaculture, 230, 359-376.

[15] National Research Council (NRC), 1983. Nutrient Requirements of Warmwater Fishes and Shellfishes. National Academic Press, Washington, DC, 103 pp.

[16] Nengas, I., Alexis, M.N., Davies, S.J., 1999. High inclusion levels of poultry meals and related by products in diets for gilthead seabream Sparus aurata L.. Aquaculture 179, 13- 23.

[17] Quartararo, N., Allan, G.L., Bell, J.D., 1998. Replacement of fish meal in diets for Australian snapper, Pagrus auratus. Aquaculture 166, 279- 295.

[18] Steffens, W., 1994. Replacing fish meal with poultry by-product meal in diets for rainbow trout, Oncorhynchus mykiss. Aquaculture 124, 27- 34.

[19] Stone, D.A.J., Allan, G.L., Parkinson, S., Rowland, S.J., 2000. Replacement of fish meal in diets for Australian silver perch, Bidyanus bidyanus III Digestibility and growth using meat meal products. Aquaculture 186, 311 -326 . 


\section{International Journal of Science and Research (IJSR) \\ ISSN (Online): 2319-7064}

Index Copernicus Value (2015): 78.96 | Impact Factor (2015): 6.391

[20] Tanksley, T.D. and Knabe, D.A., 1985. Direct measurement of amino acid digestibility in swine. In: J.W. Finley and D.T. Hopkins (Editors), Digestibility and Amino Acid Ayailability in Cereals and Oilseeds. Am. Assoc.Cereal Chemists, Inc., St. Paul, MN, pp. 259-265.

[21] Thompson, K.R., Muzinic, L.A., Christian, T.D., Webster, C.D., Manomaitis, L. and Rouse, D.B. (2003a) Lecithin requirements of juvenile Australian red claw crayfish Cherax quadricarinatus. Aquacult. Nutr., 9, 223-230.

[22] Thompson, K.R., Muzinic, L.A., Christian, T.D., Webster, C.D., Manomaitis, L. and Rouse, D.B. (2005) Effect on growth, survival, and fatty acid composition of Australian red claw crayfish Cherax quadricarinatus fed practical diets with and without supplemental lecithin and/or cholesterol. J. World Aquacult. Soc., 34, $1-10$.

[23] Webster, C.D., Thompson, K.R., Morgan, A.M., Grisby, E.J., Gannam, A.L., 2000. Use of hempseed meal, poultry by-product meal, and canola meal in practical diets without fish meal for sunshine bass (Morone chrysops M. saxatilis). Aquaculture 188, 299-309. 